\title{
TOTAL KNEE REPLACEMENT IN OSTEOARTHRITIS KNEE WITH VARUS DEFORMITY- A STUDY OF 30 CASES.
}

Prasoon Kamra1, Kalaivanan. $\mathrm{K}^{2}$.

1. Consultant, Department of Orthopaedics, JIMS, Hisar.

2. Assistant Professor, Department of Orthopedics, SMCH, chennai.

\section{CORRESPONDING AUTHOR:}

Dr. Prasoon Kamra,

H.No. 2420, sector 14,

Behind Sreeram Public School,

Hisar.

Email: prasoonkamra@yahoo.com

ABSTRACT: Osteoarthritis causes a lot of physical and mental trauma to the patient because of pain and deformity. This disease is of even more concern in country like India with an oriental life style. This study was conducted to study the efficacy of TKR (Total Knee Replacement) in their management, after pharmacological methods have failed. The results were interpreted on the basis of Knee Society Scoring system as well as Functional scoring.

The present study was carried out in Department of Orthopedics, Rajindra Hospital Patiala. This study comprised of 30 patients with osteoarthritic knee with varus deformity and their results after TKR.

KEY WORDS: osteoarthritis, TKR, varus deformity

INTRODUCTION: The advent of total knee arthroplasty in the treatment of arthritis knee has been a boon for the patients who live a miserable life due to pain, infirmity and deformity caused by arthritis, osteoarthritis being most common form of arthritis. Total knee arthroplasty is one of the most successful procedures in orthopaedic surgery today. The indications of TKR are well defined and universally accepted; subsequently the results have been uniformly excellent.

\section{INDICATIONS OF TOTAL KNEE REPLACEMENT IN OSTEOARTHRITIS}

\section{A. SYMPTOMS AND SIGNS}

(i) PAIN: The ideal candidate for surgery has moderate to severe knee pain that will be present during routine daily activities. The pain is chronic, often progressive, and is refractory to all nonsurgical modalities.

(ii) RANGE OF MOTION: Painful knee will usually lack range of motion. Patient will have both a block to full extension as well as restriction to full flexion. Although loss of motion alone is rarely an indication for knee replacement, the stiffness can be problematic especially in patients with arthritis in the adjacent joint of the lower extremities, for example in the hip joint.

(iii) DEFORMITY: Angular deformities such as genu varum or valgum associated with instability of the joint and pain in the ipsilateral hip or foot is also an indication of surgery. 
(B) DISEASE PROCESS: The above mentioned triad of knee pain, stiffness and deformity can be seen in a variety of diseases: Osteoarthritis, Rheumatoid arthritis, Seronegative spondyloarthropathies, Post Traumatic Arthritis, Tumours.

\section{CONTRAINDICATIONS TO TOTAL KNEE REPLACEMENT}

1. INFECTION: Active sepsis is an absolute contraindication to performing a knee replacement. The introduction of prosthetic material into a septic knee almost assures an increase in the severity of the inflammatory process and an eventual progression into a chronic osteomyelitic process.

2. ABSENT QUADRICEPS FUNCTION: It is an absolute contraindication to total knee replacement surgery. Arthrodesis or bracing are much better alternatives.

3. ARTHRODESIS: Painless arthrodesis in a good functional position should not be converted to a total knee replacement. Likewise, the proper treatment for a pseudoarthrosis following an attempted knee fusion is re-arthrodesis, not knee replacement.

4. RELATIVE CONTRAINDICATION: To a total knee replacement is triad of youth, obesity and a job requiring heavy use of the leg. In assessing the patient's age, the physiological and not the chronological factor is important. Obese patients are at increased risk for peri-operative anaesthesia and vascular problems, intraoperative technical problems and postoperative prosthetic loosening.

\section{AIMS AND OBJECTIVES}

1. To evaluate role of Total knee arthroplasty in patients having genu varus deformity due to osteoarthritis.

2. To evaluate the benefit of Total knee arthroplasty to the patients in daily activities in oriental life style.

3. To evaluate fixation and alignment of prosthesis radiologically and to correlate it with clinical results of total knee arthroplasty.

4. Survival of prosthesis.

MATERIAL AND METHODS: The study was conducted on the patients suffering from tricompartmental degeneration of knees, having severe pain (even at rest), contractures, varus deformity and decreased range of motion and had no relief with other conservative modes of management.

The patients were taken up from orthopaedic opd and were operated at govt. medical college \& rajindra hospital, patiala and were followed up thereafter in OPD.

The patients were evaluated pre-operatively and post-operatively according to the proforma. various prosthesis selected for replacements were ib-ii posterior stabilized prosthesis.

ASSESSMENT SYSTEM: This system of clinical rating is simple but more objective. The rating is divided into separate knee and patient function scores. Thus, increasing age or medical condition will not affect the full score. Hence dual rating system eliminates the problem of declining knee score associated with patient infirmity.

It is adopted from the knee Society, Hospital for Special Surgery, affiliated to the New York Hospital and Cornell University Medical College, New York. 
CLINICAL RATING: The system as developed by the knee society is subdivided into knee score that rates only the knee joint itself and a functional score that rates the patients ability to walk and climb stairs. This dual rating system eliminates the problem of declining knee scores associated with patient's infirmity.

\section{A. KNEE SCORE: IT INCLUDES ONLY THREE PARAMETERS.}

(i) Pain (ii) Stability (iii) Range of motion.

Total score allotted is 100 splitted as: 50 points for pain, 25 for stability, 25 for range of motion. Deduction in the score is made by:

(i) Flexion contractures (ii)Extension lag (iii)Malalignment.

Thus 100 points will be obtained by a person with no pain, with full AP/ML stability and range of motion of $125^{\circ}$

\section{B. FUNCTIONAL PARAMETER: IT INCLUDES ONLY}

(i) Walking distance (ii)Stair climbing

Total score allotted for functional parameter is also 100 where 50 points are given for walking distance (app $100 \mathrm{~m}$ ) and 50 points for stair climbing (normal if patient can ascend and descent stair without holding a railing). Deductions in functional parameters are for walking aids. The proforma attached along with are self explanatory.

The knee assessment and functional parameters are then graded as:

Excellent (85-100), Good (70-84), Fair (60-69), Poor (Less than 60)

\section{OBSERVATIONS:}

Patients were divided into three groups depending on age. The age groups were 50-59 years, 60-69 years and over 70 years. The assessment of results was on the basis of Knee Society Scoring System. The results were graded as excellent, good, fair and poor. During study the observations were as follows.

\section{Table 1: duration of disease}

\begin{tabular}{|l|l|l|l|}
\hline Duration (in Years) & Male & Female & Total \\
\hline $0-3$ & 01 & 01 & 02 \\
\hline $4-6$ & 10 & 00 & 10 \\
\hline $7-9$ & 02 & 04 & 06 \\
\hline 10 and above & 07 & 05 & 12 \\
\hline Total & 20 & 10 & 30 \\
\hline
\end{tabular}

In our study maximum no of cases, 12 in total, were operated after duration of disease was over 10 years, followed by 10 cases in the group 4-6 years duration. This was followed by 6 cases with duration of disease 7-9 years. 2 cases came for TKR within 3 years of appearance of symptoms. 


\section{ORIGINAL ARTICLE}

Table 2: relationship between duration of disease and result of tkr

\begin{tabular}{|l|l|l|l|l|l|}
\hline \multirow{2}{*}{$\begin{array}{l}\text { Duration } \\
\text { (in Years) }\end{array}$} & \multicolumn{4}{|l|}{ Results } & \multirow{2}{*}{ Total cases } \\
\cline { 2 - 5 } & P & F & G & E & \\
\hline $0-3$ & 0 & 0 & 0 & 2 & 02 \\
\hline $4-6$ & 0 & 0 & 1 & 9 & 10 \\
\hline $7-9$ & 0 & 0 & 1 & 5 & 06 \\
\hline 10 and above & 0 & 2 & 3 & 7 & 12 \\
\hline Total & 0 & 2 & 5 & 23 & 30 \\
\hline
\end{tabular}

Of the two cases with duration of disease less than 3 Years both of them manifested excellent results, among the 10 cases with duration of disease 4-6 Years, there was 1 good and 9 excellent results. 5 patients had excellent and 1 good result in patients with duration of disease 7-9 Years. In 12 patients with duration of disease above 10 Years, there were 7 excellent, 3 good and 2 fair results.

In our study in the age group of 50-59 years there were 3 patients with normal quadriceps function, 1 case with weak quadriceps and none of the cases in this age group had wasting of quadriceps. In the age group 60-69 years, these numbers were 7, 6, and 1 respectively. The corresponding numbers in the age group 70 years and above were 4, 6 and 2. In total there were 14 cases with normal, 13 cases with weak and 3 cases with wasted quadriceps.

Table 3: correlation of results of tkr and quadriceps status

\begin{tabular}{|l|l|l|l|l|l|}
\hline Quadriceps Status & Poor & Fair & Good & Excellent & Total \\
\hline Normal & 00 & 00 & 00 & 14 & 14 \\
\hline Weak & 00 & 01 & 04 & 08 & 13 \\
\hline Wasted & 00 & 01 & 01 & 01 & 03 \\
\hline Total & 00 & 02 & 05 & 23 & 30 \\
\hline
\end{tabular}

Among the 14 patients having good quadriceps function 13 patients had excellent and 2 patients had good results. Out of 13 patients with weak quadriceps, one patient had fair, 3 had good and 9 cases had excellent results. In comparison the 3 cases with wasting of quadriceps exhibited 1 each fair, good and excellent result.

Table 4: weight distribution

\begin{tabular}{|l|l|l|l|l|}
\hline Age Group (in Years) & Normal & Overweight & Obese & Total \\
\hline $50-59$ & 02 & 02 & 00 & 04 \\
\hline $69-69$ & 06 & 06 & 02 & 14 \\
\hline 70 and above & 08 & 04 & 00 & 12 \\
\hline Total & 16 & 12 & 02 & 30 \\
\hline
\end{tabular}

In our present study only 2 patients were obese, 12 were overweight and the remaining was normal in weight. The 2 cases that were obese belonged to the age group of 60-69 Years. 
Table 5: correlation of weight and result of tkr

\begin{tabular}{|l|l|l|l|l|l|}
\hline Weight & Poor & Fair & Good & Excellent & Total \\
\hline Normal & 0 & 0 & 1 & 15 & 16 \\
\hline Overweight & 0 & 1 & 3 & 08 & 12 \\
\hline Obese & 0 & 1 & 1 & 00 & 02 \\
\hline Total & 0 & 2 & 5 & 23 & 30 \\
\hline
\end{tabular}

Among the patients with normal weight there were 15 cases with excellent result, 1 with good result. Out of the 12 cases that were overweight, the results were 8 excellent, 3 good and 1 fair.

Table 6: pre operative knee grading

\begin{tabular}{|l|l|l|l|l|l|l|l|l|l|l|l|l|}
\hline \multirow{2}{*}{$\begin{array}{l}\text { Age Group } \\
\text { (in years) }\end{array}$} & \multicolumn{4}{|l|}{ Male } & Female & \multicolumn{4}{|l|}{ Total } \\
\cline { 2 - 13 }$y$ & F & G & E & P & F & G & E & P & F & G & E \\
\hline $50-59$ & 3 & 0 & 0 & 0 & 1 & 0 & 0 & 0 & 4 & 0 & 0 & 0 \\
\hline $60-69$ & 9 & 0 & 0 & 0 & 5 & 0 & 0 & 0 & 14 & 0 & 0 & 0 \\
\hline 70 and above & 8 & 0 & 0 & 0 & 4 & 0 & 0 & 0 & 12 & 0 & 0 & 0 \\
\hline Total & 20 & 0 & 0 & 0 & 10 & 0 & 0 & 0 & 30 & 0 & 0 & 0 \\
\hline
\end{tabular}

In the present study there were 3 males and 1 female in the age group 50-59 year, 9 males and 5 females in the age group of 60-69 Years, 8 males and 4 females in the age group 70 Years and above, all of them having poor grade according to knee scoring system.

Table 7: post operative knee grading

\begin{tabular}{|c|c|c|c|c|c|c|c|c|c|c|c|c|}
\hline \multirow{2}{*}{$\begin{array}{l}\text { Age Group } \\
\text { (in years) }\end{array}$} & \multicolumn{4}{|c|}{ Male } & \multicolumn{4}{|c|}{ Female } & \multicolumn{4}{|c|}{ Total } \\
\hline & $\mathbf{P}$ & $\mathbf{F}$ & $\mathbf{G}$ & $\mathbf{E}$ & $\mathbf{P}$ & $\mathbf{F}$ & $\mathbf{G}$ & $\mathbf{E}$ & $\mathbf{P}$ & $\mathbf{F}$ & G & $\mathbf{E}$ \\
\hline $50-59$ & 0 & 0 & 1 & 2 & 0 & 0 & 0 & 1 & 0 & 0 & 1 & 3 \\
\hline $60-69$ & 0 & 1 & 1 & 8 & 0 & 0 & 1 & 4 & 0 & 1 & 2 & 12 \\
\hline 70 and above & 0 & 0 & 1 & 6 & 0 & 1 & 1 & 2 & 0 & 1 & 2 & 8 \\
\hline Total & 0 & 1 & 3 & 16 & 0 & 1 & 2 & 7 & 0 & 2 & 5 & 23 \\
\hline
\end{tabular}

As is evident from the above table in the age group of 50-59 years there were excellent results in 2 males and 1 female, good result in 1 male. There were no fair or poor results in this age group. In the age group 60-69 years, among the 10 males there were 8 excellent, 1 good and 1 fair result, out of the 5 females there were 4 excellent and 1 good results i.e. in total there were 12 excellent, 2 good and 1 fair result. In the age group 70 years and above out of 7 males there were 6 excellent and 1 good result and among 4 females there were 2 excellent, 1 fair and 1 good result i.e in total there were 8 excellent, 2 good and 1 fair result. So to conclude there were 23 excellent, 5 good and 2 fair results with no poor result in our study.

DISCUSSION: Osteoarthritis is a leading cause of morbidity in elderly. This renders them sedentary and dependent upon others. TKR has emerged as an effective treatment option in osteoarthritis knee when all other measures have failed. 
1. OBESITY: Spicer \& Pomeroy et al published a study in August 2001 in which they studied the correlation of obesity (BMI) and outcome of TKR. They found that obese patients had an improvement in knee score by 41.9 points as compared to 43.7 points in normal weight person. They also found that review arthroplasty was required more often in obese patients. Changulani et al found that the average age at which patients underwent TKR was much higher in patients with normal weight as compared to their obese counter-parts. The criteria they chose for obesity was also BMI.

The findings of present study also corroborate the above mentioned studies. Considering BMI $<25$ as normal, the mean age at which these patients underwent TKR was 69 Years and in patients with BMI $>25$ this age was 63 Years. In the only 2 obese cases (BMI > 30) there was 1 fair and 1 good result hence, the in tandem with the above studies.

2. QUADRICEPS STATUS: Mizner, 2005 carried out a study in which he observed the outcome after TKR surgery and preoperative quadriceps strength and he found these variables to be proportionate to each other i.e. better functional outcomes after TKR surgery and better quadriceps strength preoperatively.

In our study, the 14 cases that had normal quadriceps strength preoperatively all of them had excellent results whereas when quadriceps was weak or wasted the results were not as good.

3. ALIGNMENT: Hvid and Nielsen carried out a study and published in 1984 and observed that there were radiolucencies in the knees of the patients in whom there was varus alignment of the knee. They observed inconsistent success in achieving the desired $2-12^{\circ}$ of valgus. KjaersgaardAnderson et al 1989 also noticed loosing of prosthesis consequent to varus implantation of the tibial component.

In present study out of the total 30 cases we were able to achieve the physiological values of $2-12^{\circ}$ in the 27 cases. No cases were observed with tibial or femoral component loosing.

4. OVERALL SUCCESS RATE: The original review in the first consecutive 220 arthroplasties was published by Insall et al in 1986 and they reported 137 (62\%) excellent, 61 (287\%) Good, 10 (4.5\%), Fair and 12 (5.5\%) poor results with a follow up of 3-5 Years in total Condylar prosthesis. In a similar study carried out by Vince and Colleagues in 1988 revealed $79.2 \%$ excellent, $16.7 \%$ good \& $4.2 \%$ poor results. Scuderi et al in 1989 carried out a study in which there was $97.3 \%$ success rate. Failures included two loose tibial components one tibial stress. There were six infections as well there were no tibial components loosing or infection in the present study carried.

In the present study the follow up was done once and the results were $77 \%$ excellent, $17 \%$ good, $6 \%$ fair and no poor results.

\section{COMPLICATIONS:}

1. PATELLAR COMPLiCATIONS: Sneppen and Colleagues (1985) noticed no patellar dislocation or fracture patella but there was moderate residual pain in 12 knees at one year follow-up. Kjaersgaard and Anderson et al, 1989 noticed a case of patellar fracture in their study of 103 osteoarthritic patients that underwent TKR. Aglietti and Buzzi (1988) published a follow-up study 
in which there were no stress fractures but their average flexion was very modest $\left(98^{\circ}\right)$ which is less than average and this is what, they proposed has protected patella.

In present study, there were no patellar complications and the range of flexion was also 106.50 .

2. INFECTION: Kjaersgaard and Anderson et al, 1989 reported 3 deep infections consequently poor results out of 103 knees that were operated i.e. infection rate was 3\%. In present study, there was no case of deep infection, presumably due to strict asepsis and antibiotics.

CONCLUSION: Maximum number of cases belonged to the age group of 60-69 Years, males turned up more for surgery in the ratio of 2:1.The duration of disease, thus can be concluded adversely affects the outcome after surgery. There were over $90 \%$ acceptable results in patients with normal or weak quadriceps and in patients in whom wasting was present there were $67 \%$ acceptable results. Nothing can be said conclusively because of the small sample size in the group with wasted quadriceps. Though this data does not conclusively suggest about the prognosis of TKR after obesity but the age of the patients which required TKR was less in overweight and obese patients as compared to patients with normal weight and this was evident as average age of patient undergoing TKR with normal weight was 67 Years as compared to 63 Years in overweight and obese patients. There was varus deformity in all the cases, which was corrected and physiological varus was achieved in $90 \%$ of the cases. Range of motion is considerably increased from a preoperative mean of $77^{\circ}$ to a postoperative $105^{\circ}$. It can thus be concluded from the present study that TKR provides an unparalleled improvement in the disease symptomatology, deformity correction, stability and life style in the patients suffering from osteoarthritis. In India where people have an oriental life style, this is possibly the best treatment for knee osteoarthritis.

\section{BIBLIOGRAPHY:}

1. Aglietti P, Buzzi R. Posterior stabilized total condylar knee replacement. Three to eight years' follow-up 85 knees. J Bone Joint Surg (Br) 1988; 70: 211.

2. Changulani $\mathrm{M}$ et al. The relationship between obesity the age at $\mathrm{C}$ hip \& knee replacement is undertaken. J. Bone Joint surg 90B 360-363.

3. Hvid I, Nielson S. Total condylar knee arthroplasty: prosthetic component positioning and radiolucent lines. Acta Orthop Scand 1984; 55:160-5.

4. Insall JN, Kelly M. The total condylar prosthesis. ClinOrthop 1986; 205:43-8.

5. Kjaersgaard-Anderson P, Hvid I, Wethelund JO, Sneppen O. Total condylar knee arthroplasty in osteoarthritis. A 4-6 year follow-up evaluation of 103 cases.ClinOrthop 1989; 238:167173.

6. Mizner R et al. J Rheumatal 2005; 32:1533-1539.

7. Scuderi GR, Insall JN. The posterior stabilized knee prosthesis. Orthop Clin Am 1989; 20(1):71-8.

8. Sneppen 0, GudmundssonGh, Bunger C. Patellofemoral function in total condylar arthroplasty. Int Orthop 1985; 9:65-68.

9. Spicer D, Pameroy D et al. BMI as a predictor of outcomes in total knee replacement. IntOrthap Rages 2001; 246-249. 


\section{ORIGINAL ARTICLE}

10. Vince KG, Kelly MA, Insall JN. The posterior stabilized knee prosthesis: Follow-up 5-8 years. Orthop Trans 1988; 12:157.

PRE-OPERATIVE ASSESSMENT:

\begin{tabular}{|c|c|c|c|c|c|c|c|c|c|c|c|c|c|c|c|c|c|c|c|c|c|c|c|c|}
\hline \multirow{3}{*}{$\begin{array}{c}\text { S. } \\
\text { No. }\end{array}$} & \multirow{3}{*}{ Name } & \multirow{3}{*}{ FFD } & \multirow{3}{*}{ FF } & \multirow{3}{*}{ ROM } & \multicolumn{2}{|c|}{ STABILITY } & \multirow{3}{*}{$\begin{array}{c}\text { Alignment } \\
\text { Varus }\end{array}$} & \multirow{3}{*}{ Walking } & \multirow{3}{*}{ Stairs } & \multirow{3}{*}{$\begin{array}{c}\text { Walking } \\
\text { Aids }\end{array}$} & \multicolumn{9}{|c|}{ KNEE SCORING } & \multicolumn{5}{|c|}{ FUNCTIONAL SCORING } \\
\hline & & & & & & & & & & & \multirow{2}{*}{ Pain } & \multirow{2}{*}{ ROM } & \multicolumn{2}{|c|}{ Stability } & \multirow{2}{*}{$\begin{array}{l}\text { Flex. } \\
\text { Cont. }\end{array}$} & \multirow{2}{*}{$\begin{array}{l}\text { Ext. } \\
\text { Lag }\end{array}$} & \multirow{2}{*}{$\begin{array}{c}\text { Alignment } \\
\text { Varus }\end{array}$} & \multirow{2}{*}{$\begin{array}{l}\text { Total } \\
\text { Score }\end{array}$} & \multirow{2}{*}{$\begin{array}{l}\text { Knee } \\
\text { Grade }\end{array}$} & \multirow{2}{*}{ Walking } & \multirow{2}{*}{ Stairs } & \multirow{2}{*}{ Ded. } & \multirow{2}{*}{$\begin{array}{l}\text { Total } \\
\text { Score }\end{array}$} & \multirow{2}{*}{$\begin{array}{l}\text { Knee } \\
\text { Grade }\end{array}$} \\
\hline & & & & & AF & IVIL & & & & & & & AP & ML & & & & & & & & & & \\
\hline 1 & $\mathrm{HR}$ & 25 & 90 & 65 & $<5$ & $<15$ & 20 & $\mathrm{C}$ & $\mathrm{C}$ & CANE & 10 & 13 & 10 & 00 & 15 & - & 20 & 00 & $\mathrm{P}$ & 30 & 30 & 05 & 55 & $\mathrm{P}$ \\
\hline 2 & AS & 05 & 105 & 100 & $<5$ & $<15$ & 10 & C & D & - & 30 & 20 & 10 & 00 & 02 & - & 00 & 58 & $\mathrm{P}$ & 30 & 15 & 00 & 45 & $\mathrm{P}$ \\
\hline 3 & MS & 20 & 110 & 90 & $<10$ & $<10$ & 15 & $\mathrm{D}$ & $\mathrm{C}$ & - & 30 & 18 & 05 & 10 & 10 & - & 15 & 38 & $\mathrm{P}$ & 20 & 20 & 00 & 40 & $\mathrm{P}$ \\
\hline 4 & RS & 10 & 110 & 100 & $<15$ & $<10$ & 10 & C & $\mathrm{C}$ & - & 20 & 20 & 00 & 05 & 05 & - & 00 & 40 & $\mathrm{P}$ & 30 & 30 & 00 & 60 & $\mathrm{~F}$ \\
\hline 5 & MS & 10 & 120 & 110 & $<10$ & $<10$ & 10 & D & D & - & 10 & 22 & 05 & 10 & 05 & - & 00 & 42 & $\mathrm{P}$ & 20 & 15 & 00 & 35 & $\mathrm{P}$ \\
\hline 6 & SD & 45 & 80 & 35 & $<5$ & $<5$ & 20 & $\mathrm{~F}$ & E & - & 00 & 07 & 10 & 15 & 15 & - & 20 & 00 & $\mathrm{P}$ & 00 & 00 & 00 & 00 & $\mathrm{P}$ \\
\hline 7 & HR & 25 & 95 & 70 & $<5$ & $<5$ & 15 & C & $\mathrm{C}$ & CANE & 10 & 15 & 10 & 15 & 15 & - & 15 & 20 & $\mathrm{P}$ & 30 & 30 & 05 & 55 & $\mathrm{P}$ \\
\hline 8 & SD & 45 & 75 & 30 & $<10$ & $<10$ & 20 & $\mathrm{~F}$ & E & - & 00 & 06 & 05 & 10 & 15 & - & 20 & 00 & $\mathrm{P}$ & 00 & 00 & 00 & 00 & $\mathrm{P}$ \\
\hline 9 & KC & 15 & 95 & 80 & $<15$ & 15 & 30 & B & C & CANE & 30 & 16 & 09 & 00 & 05 & - & 20 & 30 & $\mathrm{P}$ & 40 & 30 & 05 & 65 & $\mathrm{~F}$ \\
\hline 10 & $\mathrm{HK}$ & 10 & 80 & 70 & $<5$ & $<5$ & 10 & E & D & WALKER & 10 & 14 & 10 & 15 & 05 & - & 00 & 44 & $\mathrm{P}$ & 10 & 15 & 20 & 05 & $\mathrm{P}$ \\
\hline 11 & CK & 20 & 90 & 70 & $<5$ & $<5$ & 10 & D & D & - & 20 & 14 & 10 & 15 & 10 & - & 00 & 49 & $\mathrm{P}$ & 20 & 15 & 00 & 35 & $\mathrm{P}$ \\
\hline 12 & CL & 20 & 120 & 100 & $<10$ & $<10$ & 15 & D & C & - & 30 & 20 & 05 & 10 & 10 & - & 15 & 40 & $\mathrm{P}$ & 20 & 30 & 00 & 50 & $P$ \\
\hline 13 & DS & 10 & 110 & 100 & $<5$ & $<5$ & 15 & C & D & - & 20 & 20 & 10 & 15 & 05 & - & 15 & 45 & $\mathrm{P}$ & 30 & 15 & 00 & 45 & $P$ \\
\hline 14 & SS & 10 & 120 & 110 & $<5$ & 00 & 20 & E & D & - & 20 & 22 & 10 & 15 & 05 & - & 20 & 42 & $\mathrm{P}$ & 10 & 15 & 00 & 25 & $\mathrm{P}$ \\
\hline 15 & CK & 15 & 105 & 90 & 00 & 00 & 10 & E & D & - & 20 & 18 & 10 & 15 & 05 & - & 00 & 58 & $\mathrm{P}$ & 10 & 15 & 00 & 25 & $P$ \\
\hline
\end{tabular}




\section{ORIGINAL ARTICLE}

\begin{tabular}{|c|c|c|c|c|c|c|c|c|c|c|c|c|c|c|c|c|c|c|c|c|c|c|c|c|}
\hline \multirow{3}{*}{$\begin{array}{l}\text { S. } \\
\text { No. }\end{array}$} & \multirow{3}{*}{ Name } & \multirow{3}{*}{ FFD } & \multirow{3}{*}{$\mathbf{F F}$} & \multirow{3}{*}{ ROM } & \multicolumn{2}{|c|}{ STABILITY } & \multirow{3}{*}{$\begin{array}{c}\text { Alignment } \\
\text { Varus }\end{array}$} & \multirow{3}{*}{ Walking } & \multirow{3}{*}{ Stairs } & \multirow{3}{*}{$\begin{array}{c}\text { Walking } \\
\text { Aids }\end{array}$} & \multicolumn{9}{|c|}{ KNEE SCORING } & \multicolumn{5}{|c|}{ FUNCTIONAL SCORING } \\
\hline & & & & & & & & & & & \multirow{2}{*}{ Pain } & \multirow{2}{*}{ ROM } & \multicolumn{2}{|c|}{ Stability } & \multirow{2}{*}{$\begin{array}{l}\text { Flex. } \\
\text { Cont. }\end{array}$} & \multirow{2}{*}{$\begin{array}{l}\text { Ext. } \\
\text { Lag }\end{array}$} & \multirow{2}{*}{$\begin{array}{c}\text { Alignment } \\
\text { Varus }\end{array}$} & \multirow{2}{*}{$\begin{array}{l}\text { Total } \\
\text { Score }\end{array}$} & \multirow{2}{*}{$\begin{array}{c}\text { Knee } \\
\text { Grade }\end{array}$} & \multirow{2}{*}{ Walking } & \multirow{2}{*}{ Stairs } & \multirow{2}{*}{ Ded. } & \multirow{2}{*}{$\begin{array}{l}\text { Total } \\
\text { Score }\end{array}$} & \multirow{2}{*}{$\begin{array}{l}\text { Knee } \\
\text { Grade }\end{array}$} \\
\hline & & & & & & & & & & & & & AP & ML & & & & & & & & & & \\
\hline 16 & DS & 10 & 100 & 90 & $<15$ & $<15$ & 15 & D & $\mathrm{D}$ & CANE & 30 & 18 & 00 & 00 & 05 & - & 15 & 28 & $\mathrm{P}$ & 20 & 15 & 05 & 30 & $P$ \\
\hline 17 & SS & 30 & 90 & 60 & $<5$ & 00 & 30 & $\mathrm{D}$ & $\mathrm{C}$ & CANE & 30 & 12 & 10 & 15 & 15 & - & 15 & 37 & $P$ & 20 & 30 & 05 & 45 & $P$ \\
\hline 18 & RS & 60 & 90 & 30 & 00 & 00 & 30 & $\mathrm{E}$ & E & WALKER & 10 & 06 & 10 & 15 & 15 & - & 20 & 06 & $P$ & 10 & 00 & 20 & 00 & $P$ \\
\hline 19 & RS & 60 & 100 & 40 & 00 & 00 & 30 & E & E & WALKER & 10 & 06 & 10 & 15 & 15 & - & 20 & 08 & $P$ & 10 & 00 & 20 & 00 & $P$ \\
\hline 20 & MS & 20 & 110 & 90 & $<10$ & $<10$ & 20 & D & D & - & 20 & 18 & 05 & 10 & 10 & - & 20 & 23 & $\mathrm{P}$ & 20 & 15 & 00 & 35 & $\mathrm{P}$ \\
\hline 21 & DK & 10 & 100 & 90 & $<5$ & $<5$ & 10 & $\mathrm{C}$ & C & CANE & 10 & 18 & 10 & 15 & 05 & - & 00 & 48 & $P$ & 30 & 30 & 05 & 55 & $P$ \\
\hline 22 & RS & 10 & 90 & 80 & $<10$ & $<10$ & 15 & C & D & - & 20 & 16 & 05 & 10 & 05 & - & 15 & 31 & $P$ & 30 & 15 & 00 & 45 & $P$ \\
\hline 23 & SS & 15 & 95 & 80 & $<10$ & $<10$ & 15 & D & D & - & 20 & 16 & 05 & 10 & 05 & - & 15 & 31 & $\mathrm{P}$ & 20 & 15 & 00 & 35 & $P$ \\
\hline 24 & ML & 30 & 105 & 75 & 00 & 00 & 10 & C & D & - & 30 & 15 & 10 & 15 & 15 & - & 00 & 55 & $\mathrm{P}$ & 30 & 15 & 00 & 45 & $P$ \\
\hline 25 & SN & 25 & 110 & 85 & $<5$ & $<5$ & 15 & D & D & - & 20 & 17 & 10 & 15 & 15 & - & 15 & 32 & $P$ & 20 & 15 & 00 & 35 & $P$ \\
\hline 26 & $\mathrm{NC}$ & 30 & 90 & 60 & $<5$ & $<5$ & 10 & E & D & CANE & 20 & 12 & 10 & 15 & 15 & - & 00 & 42 & $\mathrm{P}$ & 10 & 15 & 05 & 20 & $\mathrm{P}$ \\
\hline 27 & BK & 15 & 100 & 85 & $<15$ & $<15$ & 15 & D & D & - & 30 & 17 & 00 & 00 & 5 & - & 15 & 27 & $\mathrm{P}$ & 20 & 15 & 00 & 35 & $P$ \\
\hline 28 & RS & 25 & 100 & 75 & $<5$ & $<5$ & 10 & C & C & CANE & 30 & 15 & 10 & 15 & 15 & - & 00 & 55 & $\mathrm{P}$ & 30 & 30 & 05 & 55 & $\mathrm{P}$ \\
\hline 29 & DK & 15 & 90 & 75 & 00 & 00 & 15 & D & C & - & 20 & 15 & 10 & 15 & 05 & - & 15 & 40 & $\mathrm{P}$ & 20 & 30 & 00 & 50 & $\mathrm{P}$ \\
\hline 30 & GK & 20 & 100 & 80 & $<5$ & 00 & 10 & C & C & CANE & 10 & 16 & 10 & 15 & 10 & - & 00 & 41 & $\mathrm{P}$ & 30 & 30 & 05 & 55 & $\mathrm{P}$ \\
\hline
\end{tabular}




\section{ORIGINAL ARTICLE}

\section{FOLLOW-UP ASSESSMENT}

\begin{tabular}{|c|c|c|c|c|c|c|c|c|c|c|c|c|c|c|c|c|c|c|c|c|c|c|c|c|c|c|}
\hline \multirow{3}{*}{$\begin{array}{l}\text { Sr. } \\
\text { No. }\end{array}$} & \multirow{3}{*}{$\begin{array}{c}\text { Nam } \\
\text { e }\end{array}$} & \multirow{3}{*}{$\begin{array}{c}\text { FF } \\
\text { D }\end{array}$} & \multirow{3}{*}{ FF } & \multirow{3}{*}{$\begin{array}{c}\text { RO } \\
\text { M }\end{array}$} & \multicolumn{2}{|c|}{$\begin{array}{c}\text { Stabilit } \\
y\end{array}$} & \multicolumn{2}{|c|}{ Alignment } & \multirow{3}{*}{$\begin{array}{c}\text { Walkin } \\
\text { g }\end{array}$} & \multirow{3}{*}{$\begin{array}{c}\text { Stair } \\
s\end{array}$} & \multirow{3}{*}{$\begin{array}{c}\text { Walking } \\
\text { Aids }\end{array}$} & \multicolumn{10}{|c|}{ Knee Scoring } & \multicolumn{5}{|c|}{ Functional Scoring } \\
\hline & & & & & \multirow{2}{*}{$\mathbf{A P}$} & \multirow{2}{*}{ ML } & \multirow{2}{*}{$\begin{array}{c}\text { Varu } \\
s\end{array}$} & \multirow{2}{*}{$\begin{array}{c}\text { Valgu } \\
\mathrm{s}\end{array}$} & & & & \multirow{2}{*}{$\begin{array}{c}\text { Pai } \\
\text { n }\end{array}$} & \multirow{2}{*}{$\begin{array}{l}\text { Ro } \\
\text { M }\end{array}$} & \multicolumn{2}{|c|}{$\begin{array}{c}\text { Stabilit } \\
\mathrm{y}\end{array}$} & \multirow{2}{*}{$\begin{array}{c}\text { Flex } \\
\text { Cont } \\
.\end{array}$} & \multirow{2}{*}{$\begin{array}{c}\text { Ext } \\
\text { Lag }\end{array}$} & \multicolumn{2}{|c|}{ Alignment } & \multirow{2}{*}{$\begin{array}{c}\text { Total } \\
\text { Scor } \\
\text { e }\end{array}$} & \multirow{2}{*}{$\begin{array}{c}\text { Knee } \\
\text { Grad } \\
\text { e }\end{array}$} & \multirow{2}{*}{$\begin{array}{c}\text { Walkin } \\
\text { g }\end{array}$} & \multirow{2}{*}{$\begin{array}{c}\text { Stair } \\
\text { s }\end{array}$} & \multirow{2}{*}{$\begin{array}{c}\text { Ded } \\
.\end{array}$} & & Knee \\
\hline & & & & & & & & & & & & & & AP & ML & & & $\begin{array}{c}\text { Varu } \\
\text { s }\end{array}$ & $\begin{array}{c}\text { Valgu } \\
s\end{array}$ & & & & & & e & e \\
\hline 1 & HR & 00 & $\begin{array}{c}10 \\
5\end{array}$ & 105 & 00 & 00 & 00 & 05 & A & B & CANE & 45 & 21 & 10 & 15 & 00 & - & 00 & 00 & 91 & E & 50 & 40 & 05 & 85 & E \\
\hline 2 & AS & 00 & $\begin{array}{c}10 \\
5\end{array}$ & 105 & 00 & $<05$ & 00 & 06 & A & B & - & 50 & 21 & 10 & 15 & 00 & - & 00 & 00 & 96 & E & 50 & 40 & 00 & 90 & E \\
\hline 3 & MS & 00 & $\begin{array}{c}11 \\
5\end{array}$ & 115 & 00 & 00 & 00 & 05 & A & B & CANE & 45 & 23 & 10 & 15 & 00 & - & 00 & 00 & 93 & E & 50 & 40 & 05 & 85 & E \\
\hline 4 & RS & 00 & $\begin{array}{c}11 \\
0\end{array}$ & 110 & $<05$ & 00 & 00 & 06 & A & B & - & 40 & 22 & 10 & 15 & 00 & - & 00 & 00 & 87 & E & 50 & 40 & 00 & 90 & E \\
\hline 5 & MS & 00 & $\begin{array}{c}11 \\
5\end{array}$ & 115 & 00 & 00 & 00 & 08 & A & A & - & 40 & 23 & 10 & 15 & 00 & - & 00 & 00 & 88 & E & 50 & 50 & 00 & 100 & E \\
\hline 6 & SD & 08 & 90 & 82 & 06 & 00 & 05 & 00 & B & B & $\begin{array}{c}\text { WALKE } \\
\mathrm{R}\end{array}$ & 30 & 16 & 05 & 15 & 02 & - & 00 & 00 & 64 & $\mathrm{~F}$ & 40 & 40 & 20 & 60 & $\mathrm{~F}$ \\
\hline 7 & HR & 00 & $\begin{array}{c}11 \\
0\end{array}$ & 110 & 00 & 00 & 00 & 02 & A & B & CANE & 45 & 22 & 10 & 15 & 00 & - & 00 & 04 & 88 & E & 50 & 40 & 05 & 85 & E \\
\hline 8 & SD & 08 & 95 & 87 & 00 & 00 & 05 & 00 & B & B & CANE & 40 & 17 & 10 & 15 & 02 & - & 00 & 00 & 73 & G & 40 & 40 & 05 & 75 & G \\
\hline 9 & $\mathrm{KC}$ & 00 & $\begin{array}{c}10 \\
5\end{array}$ & 105 & 08 & 07 & 05 & 00 & B & B & CANE & 45 & 21 & 05 & 10 & 00 & - & 00 & 00 & 81 & G & 40 & 40 & 05 & 75 & G \\
\hline 10 & HK & 00 & $\begin{array}{c}10 \\
0\end{array}$ & 100 & 00 & 00 & 00 & 02 & A & B & - & 45 & 20 & 10 & 15 & 00 & - & 00 & 04 & 86 & E & 50 & 40 & 00 & 90 & E \\
\hline 11 & $\mathrm{CK}$ & 00 & $\begin{array}{c}10 \\
0\end{array}$ & 100 & 00 & 00 & 00 & 05 & B & B & - & 30 & 20 & 10 & 15 & 00 & - & 00 & 00 & 75 & G & 40 & 40 & 00 & 80 & G \\
\hline 12 & CL & 00 & $\begin{array}{c}12 \\
0\end{array}$ & 120 & 00 & 00 & 00 & $<05$ & A & A & CANE & 40 & 24 & 10 & 15 & 00 & - & 00 & 00 & 89 & E & 50 & 50 & 05 & 95 & E \\
\hline 13 & DS & 00 & $\begin{array}{c}11 \\
0\end{array}$ & 110 & 00 & 00 & 00 & 06 & B & B & - & 30 & 22 & 10 & 15 & 00 & - & 00 & 00 & 77 & G & 40 & 40 & 00 & 80 & G \\
\hline 14 & SS & 00 & $\begin{array}{c}11 \\
5\end{array}$ & 115 & 00 & 00 & 00 & 06 & A & B & - & 40 & 23 & 10 & 15 & 00 & - & 00 & 00 & 88 & E & 50 & 40 & 00 & 90 & E \\
\hline 15 & CK & 00 & $\begin{array}{c}10 \\
0\end{array}$ & 100 & 00 & 00 & 00 & 05 & A & B & CANE & 40 & 20 & 10 & 15 & 00 & - & 00 & 00 & 85 & E & 50 & 40 & 05 & 85 & E \\
\hline
\end{tabular}




\section{ORIGINAL ARTICLE}

\begin{tabular}{|c|c|c|c|c|c|c|c|c|c|c|c|c|c|c|c|c|c|c|c|c|c|c|c|c|c|c|}
\hline \multirow{3}{*}{$\begin{array}{l}\text { Sr. } \\
\text { No. }\end{array}$} & \multirow{3}{*}{$\begin{array}{c}\text { Nam } \\
\text { e }\end{array}$} & \multirow{3}{*}{$\begin{array}{c}\text { FF } \\
\text { D }\end{array}$} & \multirow{3}{*}{$\mathbf{F F}$} & \multirow{3}{*}{$\begin{array}{c}\text { RO } \\
\text { M }\end{array}$} & \multicolumn{2}{|c|}{ Stability } & \multicolumn{2}{|c|}{ Alignment } & \multirow{3}{*}{$\begin{array}{c}\text { Walkin } \\
\mathrm{g}\end{array}$} & \multirow{3}{*}{$\begin{array}{c}\text { Stair } \\
\mathbf{s}\end{array}$} & \multirow{3}{*}{$\begin{array}{c}\text { Walking } \\
\text { Aids }\end{array}$} & \multicolumn{10}{|c|}{ Knee Scoring } & \multicolumn{5}{|c|}{ Functional Scoring } \\
\hline & & & & & \multirow{2}{*}{ AP } & \multirow{2}{*}{ ML } & \multirow{2}{*}{$\begin{array}{l}\text { Va } \\
\text { rus }\end{array}$} & \multirow{2}{*}{$\begin{array}{c}\text { Valgu } \\
s\end{array}$} & & & & \multirow{2}{*}{$\begin{array}{l}\text { Pa } \\
\text { in }\end{array}$} & \multirow{2}{*}{$\begin{array}{l}\text { RO } \\
\text { M }\end{array}$} & \multicolumn{2}{|c|}{$\begin{array}{c}\text { Stabilit } \\
y\end{array}$} & \multirow{2}{*}{$\begin{array}{c}\text { Flex } \\
\text { Cont } \\
.\end{array}$} & \multirow{2}{*}{$\begin{array}{c}\text { Ext } \\
\text { Lag }\end{array}$} & \multicolumn{2}{|c|}{ Alignment } & \multirow{2}{*}{$\begin{array}{c}\text { Total } \\
\text { Scor } \\
\mathbf{e}\end{array}$} & \multirow{2}{*}{$\begin{array}{c}\text { Knee } \\
\text { Grad } \\
\text { e }\end{array}$} & \multirow{2}{*}{$\begin{array}{c}\text { Walkin } \\
\mathrm{g}\end{array}$} & \multirow{2}{*}{$\begin{array}{c}\text { Stair } \\
\text { S }\end{array}$} & \multirow{2}{*}{$\begin{array}{c}\text { Ded } \\
.\end{array}$} & & Knee \\
\hline & & & & & & & & & & & & & & AP & ML & & & $\begin{array}{c}\text { Varu } \\
\text { s }\end{array}$ & $\begin{array}{c}\text { Valgu } \\
\mathrm{s}\end{array}$ & & & & & & e & e \\
\hline 16 & DS & 00 & 105 & 105 & 00 & 00 & 00 & 02 & D & B & CANE & 40 & 20 & 10 & 15 & 00 & - & 00 & 04 & 81 & G & 40 & 40 & 05 & 75 & G \\
\hline 17 & SS & 00 & 115 & 110 & 00 & 00 & 00 & 05 & A & B & - & 40 & 22 & 10 & 15 & 02 & - & 00 & 00 & 85 & $\mathrm{E}$ & 50 & 40 & 00 & 90 & $\mathrm{E}$ \\
\hline 18 & RS & 06 & 100 & 94 & $<05$ & $<05$ & 00 & 05 & B & B & WALKER & 40 & 19 & 10 & 15 & 02 & - & 00 & 00 & 82 & G & 40 & 40 & 20 & 60 & $\mathrm{~F}$ \\
\hline 19 & RS & 06 & 105 & 99 & $<05$ & $<05$ & 00 & 04 & B & B & WALKER & 30 & 20 & 10 & 15 & 02 & - & 00 & 08 & 65 & $\mathrm{~F}$ & 40 & 40 & 20 & 60 & $\mathrm{~F}$ \\
\hline 20 & MS & 00 & 105 & 105 & $<05$ & 00 & 00 & 05 & A & B & - & 40 & 21 & 10 & 15 & 00 & - & 00 & 00 & 86 & $\mathrm{E}$ & 50 & 40 & 00 & 90 & E \\
\hline 21 & DK & 00 & 102 & 102 & 00 & 00 & 00 & 05 & A & B & CANE & 45 & 20 & 10 & 15 & 00 & - & 00 & 00 & 90 & E & 50 & 40 & 05 & 85 & E \\
\hline 22 & RS & 00 & 105 & 105 & $<05$ & 00 & 00 & 05 & A & B & CANE & 45 & 21 & 10 & 15 & 00 & - & 00 & 00 & 91 & $\mathrm{E}$ & 50 & 40 & 05 & 85 & $\mathrm{E}$ \\
\hline 23 & SS & 00 & 108 & 108 & 00 & $<05$ & 00 & 06 & A & B & CANE & 40 & 22 & 10 & 15 & 00 & - & 00 & 00 & 87 & $\mathrm{E}$ & 50 & 40 & 05 & 85 & $\mathrm{E}$ \\
\hline 24 & ML & 05 & 110 & 105 & 00 & 00 & 00 & 06 & A & B & CANE & 45 & 21 & 10 & 15 & 02 & - & 00 & 00 & 89 & $\mathrm{E}$ & 50 & 40 & 05 & 85 & $\mathrm{E}$ \\
\hline 25 & SN & 05 & 115 & 110 & 00 & 00 & 00 & 05 & A & B & - & 45 & 22 & 10 & 15 & 02 & - & 00 & 00 & 90 & E & 50 & 40 & 00 & 90 & E \\
\hline 26 & NC & 00 & 110 & 110 & 00 & $<05$ & 00 & 05 & A & B & CANE & 40 & 22 & 10 & 15 & 00 & - & 00 & 00 & 87 & $\mathrm{E}$ & 50 & 40 & 05 & 85 & E \\
\hline 27 & BK & 00 & 102 & 102 & $<05$ & $<05$ & 00 & 05 & A & B & CANE & 45 & 20 & 10 & 15 & 00 & - & 00 & 00 & 90 & $\mathrm{E}$ & 50 & 40 & 05 & 85 & E \\
\hline 28 & RS & 00 & 106 & 106 & 00 & 00 & 00 & 06 & A & A & - & 40 & 21 & 10 & 15 & 00 & - & 00 & 00 & 91 & $\mathrm{E}$ & 50 & 50 & 00 & 100 & E \\
\hline 29 & DK & 00 & 100 & 100 & 00 & 00 & 00 & 06 & A & B & - & 40 & 20 & 10 & 15 & 00 & - & 00 & 00 & 90 & $\mathrm{E}$ & 50 & 40 & 00 & 90 & $\mathrm{E}$ \\
\hline 30 & GK & 00 & 110 & 110 & 00 & 00 & 00 & 06 & A & B & CANE & 40 & 22 & 10 & 15 & 00 & - & 00 & 00 & 92 & $\mathrm{E}$ & 50 & 40 & 05 & 85 & E \\
\hline
\end{tabular}

